Revista do CESP, Belo Horizonte, v.36, n.55, p. 105-122, 2016

\title{
O poeta Castilho, ou o "que há-de fazer um coração sensível" "neste terreno prosaico da vida real"
}

\section{The poet Castilho, or "what a sensible heart shall do" "in this real life's prosaic land"}

Eduardo da Cruz

Universidade Estadual do Rio de Janeiro (UERJ), Rio de Janeiro / Brasil eduardodacruz@gmail.com

Resumo: Pretendemos neste artigo acompanhar a produção poética de António Feliciano de Castilho (1800-1875) buscando ressaltar os posicionamentos estéticos e éticos que assumiu em cada momento de sua vida marcada pelas constantes mudanças políticas e sociais que ocorreram em Portugal.

Palavras-chave: António Feliciano de Castilho; poesia; romantismo.

Abstract: We intend in this article to follow the poetic production of António Feliciano de Castilho (1800-1875) seeking to emphasize the aesthetic and ethical positions he took in every moment of his life marked by the constant political and social changes which occurred in Portugal. Keywords: António Feliciano de Castilho; poetry; romanticism.

Data de recebimento: 5 de setembro de 2016 Data de aprovação: 14 de outubro de 2016 
Pretendemos aqui fazer a leitura de um poeta que publicou seus poemas dos 16 aos 63 anos de idade. Alguém que, antes de ter toda a sua criação soterrada pela crítica de uma geração de novos escritores, foi considerado o maior poeta português de seus dias, como lhe chama Alexandre Herculano em 1837². Referimo-nos a António Feliciano de Castilho (1800-1875). Apesar do processo de apagamento que sua obra sofreu, não é possível deixar de reconhecer sua importância no sistema literário da época. Recentemente, Ida Alves, ao analisar as cartas desse poeta para o romancista Camilo Castelo Branco, afirma que "mesmo que hoje seja considerado um escritor menor, não se pode simplesmente apagar sua existência 'verbal' nesse século tão rico de mudanças sociais, políticas, econômicas e históricas” (ALVES, 2014, p.12).

Sem pretendermos aqui julgar a qualidade poética de sua obra, que é vasta e irregular, por ter sido produzida ao longo de décadas, queremos acompanhar sua produção poética. Acreditamos que não é possível compreender plenamente o cenário literário daquele tempo sem conhecermos não apenas aqueles autores considerados grandes, mas também os que foram reconhecidos como tal em sua época. É preciso, portanto, romper o apagamento de Castilho. Castelo Branco Chaves, nos Cadernos da "Seara Nova", de 1938, numa época em que intelectuais estavam preocupados com o social e com uma crítica ao regime salazarista há pouco tempo instaurado em Portugal, afirmava que:

Castilho é um autor civilizado, é um produto de civilização, e manifestamente o é pelo seu idealismo honrando sempre o espiritual, pelo seu universalismo naquilo em que cultiva e respeita o que no homem há de universalmente humano, e ainda pelo seu liberalismo propugnando sempre pela liberdade de pensamento e pela emancipação social do homem. (CHAVES, 1938, p. 8).

Chaves defende, assim, que Castilho não é apenas um velho árcade desempenhando um papel que não é seu, mas um intelectual atuante e socialmente comprometido. Imagem semelhante é defendida

\footnotetext{
${ }^{1}$ É sua apreciação literária sobre a segunda edição d' A Primavera, de Castilho: "Quando as vagas dos séculos tiverem passado muitas vezes por cima dos sepulcros da geração que ora vive: quando a posteridade tiver feito inteira justiça ao maior poeta português dos nossos dias, darão as duas Primaveras argumento para o julgar" (HERCULANO, 1986, p. 193).
} 
hoje também por Ernesto Rodrigues (1999) que, em seu ensaio intitulado "A vingança de Castilho", comenta o papel de Castilho em sua luta pela educação.

Afinal, Castilho, muito antes da conhecida polêmica da Questão Coimbrã, enfrentou as tempestades políticas do século XIX perguntandose como ser poeta em meio à crise. Esperamos, portanto, a partir da leitura de sua obra, perceber como ele se posicionava em cada momento de um percurso de intensas mudanças.

Fazemos isso atentos às palavras de David Mourão-Ferreira, de 1975:

relendo agora praticamente todos os versos de Castilho, mais e mais me persuado que é urgente reabilitá-lo em parte como poeta; que essa parte corresponde, justamente, não aos poemas escritos neste [estilo sublime], mas no outro, no estilo simples; e que um livro como Amor e Melancolia - publicado, não o esqueçamos, em 1828 -, tendo sido talvez aquele que o autor posteriormente menos refundiu (quase não refundiu), apresente, sob inúmeros aspectos, características incomparavelmente mais modernas que, por exemplo, ainda mesmo as Flores sem Fruto, de Garrett, que são de 1845 (MOURÃO-FERREIRA, 1992, p. 104).

Não tem sido esta a visão comum sobre Castilho. Salgado Júnior, por exemplo, ao escrever sobre o poeta, estranha a situação desse poeta:

Creio que será difícil encontrar em qualquer época da história literária portuguesa, ou mesmo de outra nação, um caso tão estranho como é este de Castilho. Uma longa série de equívocos, próprios ou alheios, se estende em cadeia sem fim [...]. Anda nisto tudo uma espécie de comédia dos enganos, que cada vez se embrulha mais, até chegar a situações absolutamente paradoxais. E o pior é que tal comédia se não desenrola na lógica do cómico para chegar a um remate feliz. Não: só aparentemente é que é comédia, - pois que se pode descobrir que, enquanto a comédia dos enganos se desdobra, há um personagem que está, sem disso ter consciência, a desenvolver um papel trágico, - e essa personagem é sempre Castilho. [...] Se isto não é, de facto, uma farsada trágica, não sei que nome dar às vidas que se erram (SALGADO JÚNIOR, 1947, p. 52-53). 
É necessário, portanto, acompanhar essa errância castilhiana e as posições que ele assume como poeta em alguns momentos críticos de sua trajetória. Sabe-se que a carreira literária de António Feliciano de Castilho começou cedo e prolongou-se por um bom tempo. Com apenas 16 anos leva a público o longo Epicédio ${ }^{2}$; aos 18, um sobre $A$ Faustíssima Exaltação de D. João VI. O livro que ele publica a seguir, em 1821, é a primeira parte das Cartas de Eco e Narciso. Sobre ele, não é difícil dar razão a Teófilo Braga quando diz que é o mesmo assunto repetido à exaustão. Em 1822, publica A Primavera. Na segunda edição de Eco e Narciso, de 1825, são publicadas as duas partes do poema, seguido de redondilhas sobre o mesmo tema e uma explicação sobre seu novo estilo a partir do contato com a poesia do suíço Gessner:

Homens de mais imaginação que juízo, arrojaram-se acima das nuvens, vagaram por entre os astros, viram por toda a parte deuses; mas, esquecendo-se da terra e dos homens, mereceram que a verdade os desamparasse, e perderam todo o direito á estima dos amigos dos homens e da Natureza. [...]. A tempestade continúa, o horizonte ameaça brilhar ainda muito tempo com o fogo dos raios em vez da claridade pacifica do sol. Os nossos jovens litteratos se acham na mais difficil posição entre rochas escarpadas (CASTILHO, 1903, p. 16).

Ora, aos vinte e cinco anos não era Castilho um desses "jovens litteratos"? Estranhamente, ele parece se colocar, em 1825, acima dos "mancebos" a quem dedica o prólogo, ao mesmo tempo em que já despreza em parte os versos que está publicando, pois recomenda que os novos poetas esqueçam tanto as figuras mitológicas que pululavam em seus próprios escritos quanto as "rochas escarpadas", o locus horrendus característico dos poemas da escola romântica para cantar, segundo ele, "a ternura, o amor, o prazer, os campos, e a felicidade" (CASTILHO, 1903, p. 17). Deve-se cantar a "felicidade", sem se esquecer "da terra e dos homens". Seria isso possível? Talvez, se lembrarmos que Portugal devia estar passando por um momento de grande entusiasmo e expectativas após a revolução liberal e o retorno do rei e da Corte. Vencidas as primeiras dificuldades políticas, era tempo de se pensar no homem. É o tema dos

\footnotetext{
${ }^{2}$ Título completo: Epicedio na Sentida Morte da Augustissima Senhora D. Maria I. Rainha Fidelissima. Offerecido a Seu Augustissimo Filho D. João VI. Nosso Senhor.
} 
poemas que compõem $A$ Primavera. O fim do sofrimento do inverno e o desejo de renovação que acompanha a nova estação, as brincadeiras de criança, as festas entre amigos, o amor familiar, a vida numa sociedade em harmonia com a natureza. Entretanto, o prólogo de 1825, quando finalmente termina seu Cartas de Eco e Narciso, é de um tempo em que, cito mais uma vez, "a tempestade continúa, o horizonte ameaça brilhar ainda muito tempo com o fogo dos raios em vez da claridade pacifica do sol". A demora na publicação da obra completa, cujo tema não combina com o prólogo, parece ter sido responsável por interpretações que a desmerecem. Para José-Augusto França, por exemplo, a corrente poética de filiação "elmanista" que se encontrava à roda de Castilho "ficava à margem do tempo" (1993, p. 42), enquanto os "filintistas", como Garrett, adquiriam "responsabilidades novas":

Esta pequena batalha da literatura pode demonstrá-lo. As obras de Castilho e de Garrett assumem um valor exemplar: o primeiro vai cantar os amores de Eco e de Narciso, porque para si estes anos eram um "tempo de prazer suave e doce"; o segundo, no frio da mansarda de Paris, vai compor a história trágica de Camões (FRANÇA, 1993, p. 43).

O "tempo de prazer suave e doce" é o da primeira edição das Cartas, de 1821. Não queremos com isso dizer que não haja diferenças de dicção e de temas nos dois poetas. Enquanto Garrett está profundamente marcado pela campanha liberal, Castilho, cuja cegueira o impossibilita para a luta e mesmo para o exílio, precisava buscar outro meio de ação.

As agitações não demoraram a aparecer. Em 1826, com a morte de d. João VI e a questão dinástica com o golpe absolutista de d. Miguel, alguns irmãos de Castilho são presos e ele acompanha seu irmão pároco em seu retiro em S. Mamede da Castanheira do Vouga, onde fica até o fim da guerra civil, em 1834, com pequenas e furtivas deslocações até Coimbra e Lisboa. Neste período ele compõe a "Epístola ao Morgado de Assentiz", nobre cujos salões frequentara, poema que abrirá mais tarde seu volume de Excavações Poéticas. Nessa epístola, o sujeito começa apresentando seu tempo: "D'este século o estame vai fiado/ Das furias pela mão na stygia noite,/ Magnanino Assentiz: medra no fuso,/ Farto de sangue, de peçonha e léthes." E, após descrever todo o horror de seu tempo, indaga: "Que ha-de fazer um coração sensível?" Ele assume: "Se 
não posso dormir, traduzo Ovidio;/ Romantiso, edifico os meus castellos" (CASTILHO, 1904a).

Segundo o que mais tarde viria a lume, é efetivamente um dos períodos mais férteis de sua vida. Apesar de todas as atribulações pelas quais passavam a nação e sua família, o eremitério na serra, sem muitas distrações, e com o irmão pároco a servir de secretário, facilitavam a atividade literária, seja em leituras, em traduções ou em composições próprias. Não podemos esquecer que Castilho era praticamente cego e dependente de auxílio para ler e escrever.

$\mathrm{Na}$ "Epístola a Mauricio José Sendim”, litógrafo que o retratou três vezes, ele mostra certa mágoa por a natureza o ter deixado cego, dificultando assim sua arte:

Desegual foi comnosco a natureza:

amante seu feliz tu gosas d'ella,

abráçal-a com extasi, sorri-te,

descobre-te um a um seus mil encantos;

$[\ldots]$

Não assim eu: eu busco-a... ella se occulta;

chamo-a, invoco... ou não vem, ou só de longe

fugaz e esquiva se entremostra, e passa,

como visão por sonhos vaporosos; (CASTILHO, 1904b, p. 71).

Esse poema, de 1836, ajuda a compreender porque Castilho se via como diferente dos demais poetas. Talvez por isso sua obra aponte em alguns momentos dois caminhos aparentemente díspares, mas que se complementam. A percepção de si mesmo como estrangeiro, o diferente dos demais, o que tem a "harpa quebrada", a "harpa incerta", ao mesmo tempo em que nutre um desejo de glória e reconhecimento, sendo coroado por uma sociedade de poetas na "Festa da Primavera".

Sobre o difícil lugar desse poeta, analisando o Amor e Melancolia, (1828), único livro que Castilho publicou durante o governo absolutista de d. Miguel, escreveu recentemente Luís Maffei ao ler, entre outros, o poema "A Feiticeira":

Começo pelo fim: se há um sintagma axial em "A feiticeira", decerto é "desgraça eterna". Nesse poema, Castilho mostra que não enxerga apenas "luz e muita luz (...) aonde outros só vêem trevas", mas também as 
próprias "trevas" que agradaram a tantos românticos e ultrarromânticos. [...] Um tanto à margem, além da 'feiticeira da cova', também o visitante, cuja 'mão' é ‘de estrangeiro'. Se eu considerar a farta atuação intelectual de Castilho, volto à ideia de entrelugar que ele ocupou". (MAFFEI, 2015, p. 50-51).

É ideia semelhante à levantada pelo poema "As Duas Palmeiras", do mesmo livro, no qual o "solitario" poeta conversa com a palmeira que encontra em Coimbra: "Sósinhos estamos ambos/ neste retiro jocundo;/ tu, longe das mais palmeiras, / eu, livre de todo o mundo.// Conversemos se te agrada,/ conversemos bem de perto,/ como dois homens perdidos/ que se encontram no deserto" (CASTILHO, 1861, p. 104-105).

$\mathrm{O}$ vate solitário identifica-se com a única árvore estrangeira que encontra. São "como dois homens perdidos", ou pela metamorfose oposta, como "duas palmeiras". O viver sozinho, como estrangeiro, impede a glória. Da constatação de estar ainda mais alheio ao mundo vivendo no ermo, sai o desalentado poema "A Primeira Noite na Serra", referente à ida dele para a Serra do Caramulo com o irmão pároco em 1826.

Toda a minh'alma se entristece,

e se confrange, e se enoitece, ao ver que a sorte lhe destece de um sopro os áureos sonhos seus.

Sonhava aplausos, glória... em desterro desperto!

sonhava mundo... acho um deserto!

sonhava inda ilusões... e escuto-lhes o adeus"

Náufrago, perco a lira em meio da viagem.

$[\ldots]$

Ai! mundo! ai! ecos sedutores!

Tanto vate a ceifar louvores!...

Tanto moço a colher amores!...

Tantos loireiros e rosas!...

E eu nesta solidão a torcer-me arraigado, qual roble que geme indignado, vendo ao longe no Oceano os lenhos triunfais! (CASTILHO, 1861)

Enquanto os vates estão "a ceifar louvores", ele "geme indignado". Para ser poeta e ter glória era preciso a vida em sociedade. 
"Ermo para ambições, é inferno, e não ermo", cantava ele. Por isso, no longo retiro a que foi obrigado a viver em Castanheira do Vouga, ele abraça "os bons amigos de Ulysséa" "pela lanterna magica da mente", como indica na "Epístola ao Morgado de Assentiz". Afinal, justificava ele na "Chave do Enigma", de 1861:

os poetas, na sua qualidade de pintores, só reproduzem apparencias, perseguem sombras; e, combinando-as e variando-as ao sabor da phantasia e do gosto, aquecendo-as de affecto, e arraiando-as de idealidade, criam para a alma, dentro num mundo phantastico, outro mundo ainda mais phantastico. Não é assim? (CASTILHO, 1861, p. 385).

Com o fim da guerra civil, em 1834, era o tempo de transformar os mundos fantásticos em um país real e liberal. Ele e seus irmãos participavam ativamente da vida política na imprensa periódica, reiterando sua posição de liberais ao mesmo tempo em que atacavam o governo. A situação se agravou com a Revolução de Setembro, em 1836, que depôs a Carta e reinstaurou a Constituição de 1822 que restringia o poder do monarca e da nobreza. Essa transição não foi pacífica e havia o temor do retorno ao absolutismo como reação ao movimento popular que tomou as ruas de Lisboa.

Os literatos cartistas atacaram a violência política. Herculano publica $A$ Voz do Profeta (1836-1837) ${ }^{3}$. Castilho, nas páginas do jornal $O$ Independente e também em livro, lança seu Tributo Portuguez á Memoria do Libertador. Trata-se da reunião de textos dedicados a d. Pedro que ele havia publicado anonimamente desde 1834.

O último texto é inspirado numa litogravura de Maurício Sendim (fig. 1), também de reação à revolução de Setembro, que retrata a rainha d. Maria II chorando abraçada ao busto de seu pai, d. Pedro. Castilho imagina-a lamentando pelo destino de seu povo e perguntando, amedrontada: "uma vez trasbordada a torrente popular, quem assignará limites ás suas desvastações?" (CASTILHO, 1836b, p.782). Ao fim do texto, refletindo sobre o que escrevera, Castilho interroga-se:

Mas não acabo eu de commetter uma grande imprudencia, fazendo vibrar a corda do amor perto de homens que pretendem dormir na falsa segurança do odio? Sim, mas tal

\footnotetext{
${ }^{3}$ Reeditado no primeiro volume de Opúsculos.
} 
é a naturesa e o fado do Poeta: independente, conservando alguma cousa de sua altiveza silvestre e primitiva, perfere divagar pelos rochedos ermos e á beira dos precipicios a curvar-se na planicie para colher alguns fructos por baixo de plantas rasteiras. (CASTILHO, 1836b)

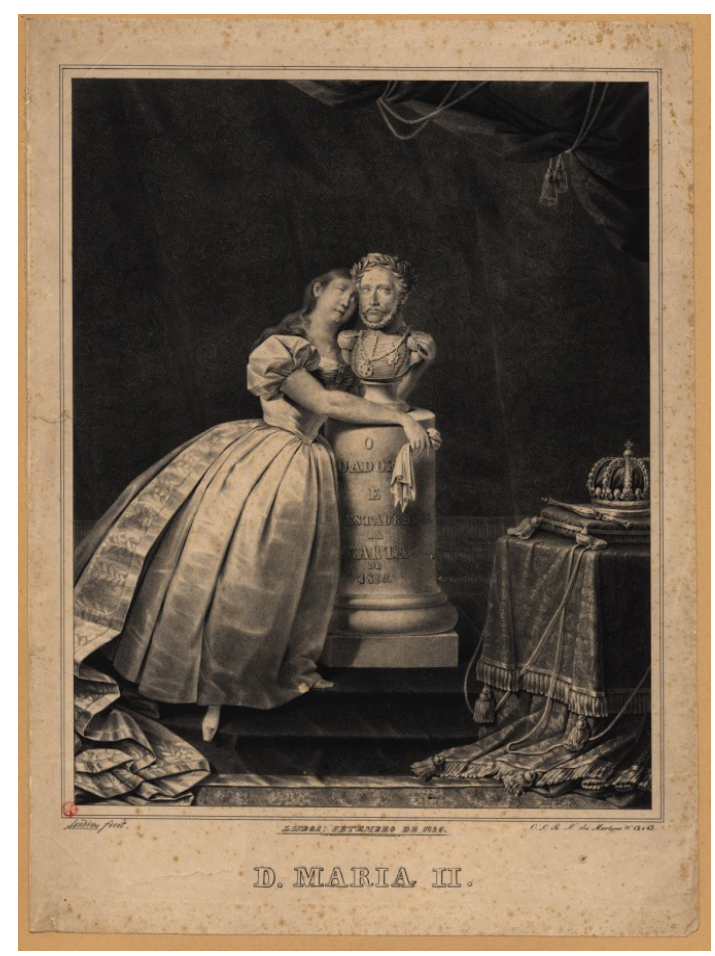

Fig. 1 - SENDIM, Maurício José do Carmo (1786-1870).

D. Maria II [Visual gráfico / Sendim fecit. - Lisboa: 1836 ([Lisboa]:

O.L. R. dos Martyres, $\mathrm{n}^{\mathrm{o}} 12$ e 13).

Disponível em: $<$ http://purl.pt/6856>

O poeta deve levar o amor aos que esperam ódio, por mais difícil que seja o caminho. Não o atrai a violência, apesar de se considerar um herói por ser poeta de ação. Afirma ele, "é a poesia a heroicidade em discurso, como a heroicidade não é mais que a poesia em acção" (CASTILHO, 1836b, p. 795) Seu percurso heróico é lutar pela verdade, uma luta lenta e pacífica. "Corre a vida do poeta por fóra do mundo; 
mas quando a sua barca passa por diante donde a verdade, ou a virtude vão de vencida, quem lhe prohibirá lançar para a terra o seu grito de reprovação, e continuar a correr indolentemente á mercê do vento do céo?" (CASTILHO, 1836b, p.807) Sua independência como poeta e político tem a ver com sua história de vida nas fileiras liberais. Além de ter ficado em Castanheira do Vouga enquanto os liberais exilados organizavam-se em partidos e facções no exterior, ele teve uma atitude de crítica aos liberais que assumiram os cargos de poder em 1834 (“devoristas") e agora, em 1836, vem a público criticar também os setembristas.

Seu livro anti-setembrista teve 3 edições só em 1836. Como homem atento ao mercado, Castilho aproveita a ocasião e lança a publicação conjunta d'A Noite do Castelo e d'Os Ciúmes do Bardo, que ele já estava compondo há seis anos, conforme a "epístola ao morgado de Assentiz": "Romantiso, edifico os meus castellos" (CASTILHO, 1904a) Foi outro livro não composto para o público, como ele afirmava não ter sido Amor e Melancolia. O motivo era claramente político:

A primeira censura, com que muitos o hão-de desdenhar,
até sem o lerem, será que vem elle intempestivo nesta
quadra epidemica dos Jornaes; que onde se ouvem de toda
a parte queixumes e lamentos, sustos e desconfianças,
um cantar de amores dissoa, como canção de noivado em
cemiterio; [...] neste terreno prosaico da vida real só
poderiam ser ainda acceitos aquelles canticos patrioticos;
[...] mas nem a mim me coube esse condão de arrastar
as multidões; nem som de trombetas resuscita defuntos;
nem eu quero desperdiçar mais com ingratos estes restos
de minha mocidade. (CASTILHO, 1836a, p. XIII-XIV -
grifos nossos).

Aqui está a defesa de um tipo de poesia que vai marcar sua obra e distanciá-lo de Garrett e de Herculano. Os "canticos patrioticos" que vão pensar politicamente o país não o animam, nem Castilho acredita que mudem efetivamente a sociedade. Essa atitude e essa poesia parecem para ele tão distantes do que via em seu país que imagina esse "cantar de amores" "como canção de noivado em cemiterio". Logo ele, que poucos meses antes, "nesta quadra epidemica dos Jornaes", posicionava-se como poeta independente que descia de sua barca para reprovar a sociedade. 
Sua experiência política deve ter demonstrado que não era possível arrastar multidões com poesia. "Neutral sou", afirmava Castilho nesse mesmo prefácio, sem assumir posição na batalha entre clássicos e românticos. A aparente neutralidade política lhe dá liberdade para atuar de diversas maneiras num Portugal cujos governos tinham dificuldade para defender sua legitimidade e não ficavam muito tempo no poder.

Em 1837, ainda aproveitando o reconhecimento público, ele publicou uma "mais correcta, emendada, e copiosissimamente accrescentada" edição da Primavera. Castilho escreveu diversos paratextos para defender a reedição de poemas de exaltação da natureza, da amizade e do amor familiar. O motivo era: "a poesia amavel [...] afastou-se d'entre nós, [...] foi reclinar-se á espera na beira da torrente dos dias" (CASTILHO, 1837). E o que se ganhou? Liberdade? Felicidade? O "que realmente faz homens livres e felizes, não é a Furia que destrua tão venerandos objectos; ama-os, defende-os, reforma-os [...]" (CASTILHO, 1837). A liberdade, tão cara aos liberais e defendida inclusive por Castilho em diversos poemas, é vista por ele, ainda na corrente da Revolução de Setembro, como algo que foi usado e deturpado. O caminho para a felicidade defendido por ele não é a revolta, mas a reforma. É esta a ideia que ele passa a defender até o fim de sua vida.

Em 1844, ele volta a publicar um livro de poemas, em plena ditadura cabralista - defendida por ele por ter restaurado a Carta. Era apenas a reunião de escritos de diversas épocas, as Excavações Poéticas, que Castilho reconhecia que não possuía relação com o que se produzia então:

a Poesia portugueza, como a do restante da Europa, e a nossa mesma Linguagem, se andam, ha annos, revolvendo para um futuro que ainda se não enxérga nem distinto; e que tudo que nós fazemos n'este genero, mormente os que ainda, como eu, retiveram (máu grado seu) alguma coisa, e muito, de certos habitos tradicionaes e viciosos em Litteratura, teem e temos de ficar esquecidos diante da brilhante escola que já por ventura vem raiando [...] onde nós outros nos não será dado penetrar" (CASTILHO, 1904, p. 12).

Seus poemas "escavados" não tinham lugar entre a literatura nova que surgia. Serviam, contudo, para marcar uma posição como 
herdeiro de uma tradição e mestre da geração nova. Vitorino Nemésio, n'A Mocidade de Herculano, ao comentar a epístola de Castilho ao Morgado de Assentis, que abre esse volume de recolhas, e os encontros na Tebaida como "derradeiro painel do século XVIII moribundo", aponta Castilho como "hífen de duas épocas mais por razões subtis de sensibilidade retardada do que por fortes imperativos de cronologia e de clima" (NEMÉSIO, 2003, p. 230 - grifos do autor). É na Revista Universal Lisbonense, que Castilho redigiu entre janeiro de 1842 e junho de 1845, que ele pretende marcar definitivamente sua posição na ligação entre duas épocas poéticas, sendo ele próprio ponto de virada. No campo arruinado pela nova literatura que começa a criar uma relva florida, Castilho coloca-se como aquele que ajudou a destruir o que foi, salvou algumas ruínas e adubou as novas flores.

Em um artigo seu sobre a nova geração de poetas, a história da literatura portuguesa é vista como uma paisagem feliz construída horizonte a horizonte, camada sobre camada, umas mais férteis do que outras, a partir da revolução que levou a ruínas o "mundo velho", tanto político quanto literário. Para ele, esses jovens poetas

são a primeira vegetação, que principía a apparecer e florir sobre as ruinas tristes e estéreis do nosso mundo velho; se não produzirem já fructo, no seu logar e no seu pó virão depois arreigar-se plantas mais felizes, que formando o terreno a outras, ainda mais corpulentas e abençoadas do que ellas, haverão egualmente contribuido, para que sumidas e talvez esquecidas as ruinas - sobre ellas, em chão assente e formoso se disfructem días de abundancia, de paz, de contentamento (CASTILHO, 1843, II, n. 24, 02/03/, p. 304).

Da literatura do passado pouco restava. Francisco Joaquim Bingre, já octogenário, "ultimo representante que ainda ahi ha da alegre sociedade e poetica eschola d'Elmano", ainda chega a enviar um poema para a Revista, "A Grande Barca da Romana Egreja". Para Castilho, Bingre é "a columna, que permanece em pé no meio das ruinas de um bello edificio, e de cujo capitel, revestido de musgo, sáe um canto de ave, que no meio da solidão aviva e poetisa ainda mais as saudades do que passou" (CASTILHO, 1844, III, n. 24, 01/02/, p. 290). Castilho interessase pelo futuro da poesia e comenta que, após algumas gerações passarem, 
"virão homens [...] que intendam que o individuo e a sociedade se não manteem de pão unicamente, [...] homens emfim, cujos argumentos se não cifrarão todos em calcular forças mechânicas" (CASTILHO, 1843, II, n. 24, 02/03/, p. 304). Afinal, para ele, o "materialismo do viver, filho do materialismo do pensar ou antes do não pensar" está em crise e é "insufficiente para o verdadeiro fim por que a nossa especie se reune, que é a satisfação recíproca e a satisfação mútua" (CASTILHO, 1843, II, n. 24, 02/03/, p. 304).

Quem são, portanto, os opositores desse "materialismo" que pensa apenas pelo "calcular de forças mechânicas" e que não contribui para a "satisfação", ou melhor dizendo, para a felicidade - preocupação constante de nosso velho poeta? São os "defensores zelosos das doctrinas antiquissimo-novissimas". A crítica do redator é clara, uma reação à modernidade capitalista, industrial, acumuladora, "materialista", burguesa, racional, que retirou do mundo a possibilidade de satisfação de algo mais do que a fome. A arma contra essa modernidade é praticamente uma antítese, andar na "contramão da modernidade" nas palavras de Michael Löwy e Robert Sayer (LÖWY; SAYER, 1995). Mais uma vez, em poucas palavras, António Feliciano de Castilho expõe a grande problemática romântica: lutar contra o avanço da modernidade a partir de algo do passado ("antiquissimo") sem abdicar da própria modernidade ("novissima"). E o grande soldado nessa luta contra o mundo prosaico é o poeta. João de Lemos é "um novo campeão, que vae entrar na lice com o escudo ainda liso, mas forte com seus vinte annos, com a inteireza do seu coração, com a virgindade da sua fé" (CASTILHO, 1843, II, n. 24, 02/03/).

Sem emprego em Lisboa, após ter deixado a redação da Revista Universal Lisbonense, que o ocupou entre janeiro de 1842 e junho de 1845, Castilho parte para os Açores. Lá ele escreve Estreias PoéticoMusicais. Como pode um poeta estrear-se aos 53 anos se publica desde os 16? São composições coetâneas da Felicidade pela Agricultura, da Felicidade pela Educação e de seu Método de alfabetização. A seu amigo Silva Túlio, diretor do periódico A Semana, que lhe pedira uma poesia, Castilho explica o que se passava. A carta é de 1 de janeiro de 1851:

o poeta, a quem me era forçoso recorrer para tal desempenho, o meu amigo de infancia, e com quem vivi inseparavel cincoenta annos, enterrei-o eu mesmo por minhas mãos, como já vos disse; e enterrei-o vivo, que foi 
uma grande lástima. Quizeram-n-o os fados assim. Jáz com muitas braçadas de terra em cima, e ha-de jazer, que já o não posso ressurgir (CASTILHO, 1907b, p. 145).

A esse poeta sob a terra, conta o autor que "Cartas namoradas, Primaveras, e todas essas vaidades literarias, já não lh'as peço, nem quero" (CASTILHO, 1907b, p. 146), renunciando a parte de sua produção poética anterior. Quer ele "contribuir para o melhoramento humano pela Poesia" (CASTILHO, 1907b, p. 147). Em carta ao compositor Norberto dos Santos Pinto, de 21 de agosto de 1852, também incluída no volume das Estreias, António Feliciano assume sua nova relação com a poesia:

Para melhor me poder entregar, e entregar-me todo, ao magisterio santo das primeiras-letras, tinha eu enterrado o poeta que em mim havia, como muitas braças para baixo d'elle enterrára o politico. O politico, ninguem m'o ha-de jámais ressuscitar; mas o poeta, vou evocal-o eu mesmo, a ver se ainda me traz algum canto de civilisação (CASTILHO, 1907b, p. 158).

A carta à rainha, que abre o livro, remete-a aos seus dois primeiros livros dedicados a d. Maria I e a d. João VI. Não podemos esquecer que Castilho era hábil em dedicatórias e outras estratégias de divulgação de suas obras. No prólogo desse livro, ele aponta o que há efetivamente de novidade: as flores que ele canta são agora "frutíferas". Delas era preciso "exprimir-se algum proveito real" (CASTILHO, 1907b, p. 18). Ele esperava que outros alargassem "a ténue senda que encetou" para criar uma "Poesia nova, refeita de fé, de esperança, e de caridade, uma Poesia sizuda, activa, e productora" para a "desanimação em que deixaram os espiritos os trinta annos tumultuarios e incriveis que atravessamos" (CASTILHO, 1907b, p. 19). Informa, então, que esses seus cantos nasceram do entusiasmo da abertura de nova legislatura de representantes do povo. Era a regeneração em poesia após a Regeneração política, período iniciado em 1851 após o fim da ditadura de Costa Cabral.

Em 1862, Castilho publica seu último volume de poemas, Outono, dedicado ao rei d. Luís. Os assuntos dos poemas são os mais variados e incluem muitos dedicados aos monarcas portugueses e brasileiros, numa campanha pública pela defesa do Método de Leitura Repentina e da educação infantil nos dois países. Porque, 
a Poesia, na sua accepção ampla e verdadeira, é o antever de muito longe, o ousar denodado, o cravar olhos no sol do ideal sem trepidar, e ver no homem, tão claramente como o corpo que pede pão e vestido, um espirito que exige luz, um coração que só de amores se alimenta. Isto é a Poesia; e esta Poesia é a que está predestinada a ser Política (CASTILHO, 1905c, p. 9).

O Castilho político podia estar há muito enterrado, mas o poeta, que mais uma vez se levantava, não podia esquecer "dos homens e da terra".

O que ressalta em quase todas essas produções, desde 1816, é uma ética, uma preocupação com o humano, na luta pela liberdade ou na tentativa de evocação de uma fantasia que sirva de escape ao tumulto prosaico de seu tempo. Alheia aparentemente da política partidária e das revoluções, nunca deixa de lutar por uma transformação social, mesmo que paulatina, pela reforma que a educação pode trazer. Ao mesmo tempo, nota-se o desejo de um poeta que quer se perpetuar, assumir-se como ponto de viragem da tradição, pela retomada dos clássicos e pela abertura de novas sendas poéticas às gerações subsequentes. É uma luta constante entre o poeta, o político e o produtor cultural.

Castilho, sobre todas as tarefas que executou, colocava como superior a de poeta, não apenas por seu canto, mas por sua ação. É o que ele assume em um dos textos da polêmica Questão Coimbrã, a "Conversação Preambular" que acompanha o D. Jaime, de Tomás Ribeiro, de 1862. Nesse paratexto, ele identifica três grandes poetas em Portugal, sendo um deles, claro, Camões. Enquanto que, "no meio d'este silencio gelado, só dois, que eu saiba, se obstinam em poetar" (CASTILHO, 1868, p. LXIX), Mendes Leal com seus dramas, e ele próprio. Sua obra seria ainda maior, dizia ele: "se me não atassem as mãos, que forcejam por executal-o, não de rimas, nem de obras para já, mas de felicidade publica a medrar pelas eras álem" (CASTILHO, 1868 , p. LXX), pois "nunca desde todo o principio larguei o culto do bello senão pelo do mais bello: nunca desci do Parnazo senão para entrar na escola" (CASTILHO, 1868, p. LXIX). Para ele, sua vida era a poesia, sendo que esta era a atuação social pela renovação, era a busca constante da felicidade pública. O resultado é o que conhecemos, e que ele já esperava: "Todos tres estamos pagos do nosso patriotismo: todos achámos a ingratidão" (CASTILHO, 1868, p. LXX). 


\section{Referências}

ALVES, Ida F. António Feliciano de Castilho: visitação a uma obra esquecida. In: ALVES, Ida; CRUZ, Eduardo da (Org.). Para não esquecer Castilho: cultura literária oitocentista. Niterói: EdUFF, 2014.

BRAGA. Teófilo. História da Literatura Portuguesa - V-O Romantismo. Mem Martins: Publicações Europa-América, [s.d.].

CASTILHO, António Feliciano de. Amor e melancolia ou A novíssima Heloísa - nova edição correta e acrescentada. Lisboa: Tipografia da Sociedade Tipográfica franco-portuguesa, 1861.

CASTILHO, António Feliciano de. A Faustissima Exaltação de Sua Magestade Fidelissima o Senhor D. João VI ao throno. Lisboa: Impressão Régia, 1818.

CASTILHO, António Feliciano de. Cartas de Echo e Narciso. 4a. ed. Coimbra: Imprensa da Universidade, 1843.

CASTILHO, António Feliciano de. Conversação Preambular. RIBEIRO, Thomaz. D. Jayme ou A Dominação de Castella (poema). $3^{\mathrm{a}}$. ed. correcta. Porto: Casa da Viuva Moré - Editora, 1868.

CASTILHO, António Feliciano de. Elegia á Morte da Chronica Constitucional de Lisboa. Lisboa: Imprensa da Rua dos Fanqueiros n. 129B, 1834.

CASTILHO, António Feliciano de. Epicedio na sentida morte da augustissima senhora D. Maria I, rainha fidelissima, offerecido a seu augustissimo filho D. João VI, nosso senhor. Jornal de Coimbra, n. L, Parte II, p. 73-97, 1817.

CASTILHO, António Feliciano de. Estreias Poetico-Musicaes para o Anno LIII. Lisboa: Typ. Universal, 1853.

CASTILHO, António Feliciano de. Estreias Poetico-Musicaes para o anno 53. Versos, com musica por diversos compositores, e traducções várias em castelhano, italiano, e allemão. Lisboa: Empreza da Historia de Portugal, 1907b.

CASTILHO, António Feliciano de. Excavações Poéticas. Rio de Janeiro: Eduardo e Henrique Laemmert, 1846. 
CASTILHO, António Feliciano de. Excavações Poeticas. Lisboa: Empreza da Historia de Portugal, 1904a. v. 1.

CASTILHO, António Feliciano de. Excavações Poeticas. Lisboa: Empreza da Historia de Portugal, 1904b. v. 2.

CASTILHO, António Feliciano de. Excavações Poeticas. Lisboa: Empreza da Historia de Portugal, 1905a. v. 3.

CASTILHO, António Feliciano de. Felicidade pela Agricultura. Rio de Janeiro: Dois Mundos Editora, [1942].

CASTILHO, António Feliciano de. Felicidade pela Instrucção. Lisboa: Typographia da Academia R. das Sciencias, 1854.

CASTILHO, António Feliciano de. Artigo em O Independente, Lisboa: $1836 \mathrm{c}$.

CASTILHO, António Feliciano de. A Noite do Castello e Os Ciumes do Bardo. Poemas seguidos da Confissão de Amelia Traduzida de M.elle Delfine Gay por A. Feliciano de Castilho. Lisboa: Typ. Lisbonense A. C. Dias, 1836a.

CASTILHO, António Feliciano de. A Noite do Castello: poema em quatro cantos. Lisboa: Empreza da Historia de Portugal, 1907c.

CASTILHO, António Feliciano de. Novas Excavações Poeticas. Lisboa: Empreza da Historia de Portugal, 1905b. 3 v.

CASTILHO, António Feliciano de. O Outono: collecção de poesias. Lisboa: Imp. Nacional, 1863.

CASTILHO, António Feliciano de. O Outomno. Lisboa: Empreza da Historia de Portugal, 1905c. 2 v.

CASTILHO, António Feliciano de. Poesias. Selecção, prefácio, concatenação e notas de João de Almeida Lucas. Lisboa: Livraria Clássica Editora, 1943.

CASTILHO, António Feliciano de. A Primavera: collecção de poemetos. Lisboa: Typographia de M. P. de Lacerda, 1822.

CASTILHO, António Feliciano de. A Primavera. 2a ${ }^{\text {a }}$ ed. Lisboa: Typographia de A. J. S. de Bulhões, 1837. 
CASTILHO, António Feliciano de. A Primavera. $3^{\text {a }}$. ed. Lisboa: Empreza da Historia de Portugal, 1903. 2 v.

CASTILHO, António Feliciano de. Tributo Portuguez á Memoria do Libertador. $3^{\text {a }}$. ed. ornada, além das outras lithographias, com a do quadro do Sr. Sendim. Lisboa: Impressão de Galhardo e Irmãos, 1836b.

CHAVES, Castelo Branco. Castilho (Alguns aspectos vivos da sua obra). Lisboa: Seara Nova, 1938. (Col. Cadernos da Seara Nova; Estudos Literários).

FRANÇA, José-Augusto. O Romantismo em Portugal: Estudo de factos socioculturais. $2^{\mathrm{a}}$. ed. Lisboa: Livros Horizonte, 1993.

HERCULANO, Alexandre. A Primavera - poema do sr. Castilho. In: Opúsculos $V$. Edição crítica. Organização, introdução e notas de Jorge Custódio e José Manuel Garcia. Porto: Editorial Presença, 1986.

HERCULANO, Alexandre. Opúsculos I. $7^{\text {a }}$. ed. Amadora: Bertrand, [s.d.].

LÖWY, Michael; SAYRE, Robert. Romantismo na contramão da modernidade. Petrópolis: Vozes, 1995.

MAFFEI, Luís. Castilho, Poeta. In: ALVES, Ida; CRUZ, Eduardo da. (Org.). Para não esquecer Castilho: cultura literária oitocentista. Niterói: EdUFF, 2014.

MOURÃO-FERREIRA, David. António Feliciano de Castilho, poeta. In: Tópicos recuperados. Lisboa: Caminho, 1992.

NEMÉSIO, Vitorino. A Mocidade de Herculano até a volta do exílio (1810-1832). Lisboa: Imprensa Nacional - Casa da Moeda, 2003.

REVISTA Universal Lisbonense, Lisboa: 1841-1859.

RODRIGUES, Ernesto. Cultura Literária Oitocentista. Porto: Lello Editores, 1999.

SALGADO JUNIOR, António. António Feliciano de Castilho. In: SIMÕES, Gaspar. Perspectiva da Literatura Portuguesa do Século XIX. Direção, Prefácio e Notas de João Gaspar Simões. Lisboa: Ática, 1947. 